\title{
Pengaruh Variasi Konsentrasi Propilen Glikol sebagai Enhancer terhadap Sediaan Transdermal Patch Ibuprofen in Vitro
}

\author{
Misnamayanti*1, Hajar Sugihantoro ${ }^{1}$ and Begum Fauziyah ${ }^{1}$ \\ ${ }^{1}$ Department of Pharmacy, Faculty of Medicine and Health Sciences, UIN Maulana Malik Ibrahim Malang, East Java, Indonesia \\ *E-mail: misnamayanti10@mail.com
}

\begin{abstract}
Ibuprofen is an anti-inflammatory class of non-steroidal propionic acid used in the treatment of osteoarthritis, analgesics, and antipyretics. Ibuprofen made in a transdermal patch to avoid side effects of irritation to the stomach, first pass effect on application oral. This aims of the research to determine the physical characteristics of the patch, the effect of propylene glycol concentration (150 mg, $200 \mathrm{mg}, 250 \mathrm{mg}$ ) on the thickness patch, $\mathrm{pH}$, and the rate of penetration as increase in penetration of the ibuprofen transdermal patch. Patch preparations were made in 3 draft formulas with varying concentrations of propylene glycol $150 \mathrm{mg}, 200 \mathrm{mg}$, and $250 \mathrm{mg}$. The method used for penetration testing is Franz diffusion cells. The results of physical characteristics are clear, odorless, dry, not cracked,> 300 folds, thickness ranges from 0.142 to 0.184 . The concentration of propylene glycol effects ( $p$-value > 0.05 ) the penetration and no effect ( $p$-value $>0.05)$ the $p H$ test. Increasing the concentration of propylene glycol causes an increase medicine that penetrate the skin.
\end{abstract}

Keywords: Ibuprofen, transdermal patch, propylene glycol

\begin{abstract}
ABSTRAK
Ibuprofen merupakan obat golongan anti inflamsi non steroid derivat asam propionat yang digunakan dalam pengobatan osteoarthritis, analgesik, antipiretik. Ibuprofen dibuat dalam transdermal patch untuk menghindari efek samping iritasi pada lambung, first pass effect pada penggunaan peroral. Penelitian ini bertujuan untuk mengetahui karakteristik fisik patch, pengaruh konsentrasi propilen glikol (150 mg, $200 \mathrm{mg}, 250 \mathrm{mg}$ ) terhadap ketebalan patch, ketahanan lipat, pH, dan laju penetrasi sebagai peningkat penetrasi sediaan transdermal patch ibuprofen. Sediaan patch dibuat 3 rancangan formula dengan variasi konsentrasi propilen glikol $150 \mathrm{mg}, 200 \mathrm{mg}$, dan $250 \mathrm{mg}$. Metode yang digunakan untuk uji penetrasi yaitu sel difusi franz. Hasil karakteristik fisik yaitu bening, tidak berbau, kering, tidak retak, >300 kali lipatan, ketebalan berkisar 0,142-0,184, Konsentrasi propilen glikol berpengaruh $(p$-value $<0,05)$ terhadap laju penetrasi dan tidak berpengaruh $(p$-value $>0,05)$ terhadap uji pH. Peningkatan konsentrasi propilen glikol menyebabkan meningkatnya jumlah obat yang berpenetrasi kedalam kulit.

Kata kunci: Ibuprofen, transdermal patch, propilen glikol

\section{Pendahuluan}

Ibuprofen merupakan golongan NSAID turunan asam propionat yang menghambat enzim siklooksigenase-1 (COX1) dan enzim siklooksigenase-2 (COX-2) yang biasanya diberikan melalui rute peroral untuk pengobatan berbagai macam penyakit rematik [1]. Ibuprofen juga dapat digunakan untuk nyeri ringan sampai sedang termasuk dysmenorrhoea, analgesik pasca operasi, migrain, sakit gigi, dan demam [2]. Obat ibuprofen mempunyai efek samping yang sama dengan golongan obat NSAID yakni dapat menyebabkan gangguan

pada saluran pencernaan sekitar 5-15\% seperti mual, muntah, erosi lambung, dan sakit kepala [3]. Untuk mengatasi masalah ini maka dibuat ibuprofen dalam bentuk sediaan topikal yaitu sediaan transdermal. Penghantaran obat secara transdermal mempunyai keuntungan yaitu memberikan pelepasan obat konstan, penghantaran obat terkontrol, menghindari first pass metabolism, mencegah iritasi pada saluran pencernaan, dan cara penggunaan yang mudah [4]. Berdasarkan kelebihan tersebut maka ibuprofen dapat diformulasikan dalam bentuk transdermal patch.
\end{abstract}


Patch merupakan salah satu sediaan yang dapat menghantarkan dosis obat secara terkendali melalui kulit dalam periode waktu tertentu. Berdasarkan metode formulasinya, patch dibagi menjadi dua yaitu membran controlled system dan matrix controlled system. Pada penelitian ini digunakan matrix controlled system karena mempunyai keuntungan yaitu dapat menghasilkan sediaan patch yang tipis dan elegan, sehingga nyaman untuk digunakan, proses pembuatan yang mudah, cepat, dan murah dibandingkan dengan membran controlled system [5].

Stratum corneum adalah lapisan terluar kulit yang terdiri dari sel-sel gepeng yang mati, tidak berinti, dan protoplasmanya berubah menjadi keratin (zat tanduk). Laju penetrasi obat melalui stratum corneum dapat meningkat dengan adanya peningkat penetrasi. Salah satu contoh peningkat penetrasi yaitu propilen glikol yang memiliki mekanisme mempengaruhi kelarutan bahan aktif didalam kulit dan berinteraksi dengan lapisan stratum corneum, sehingga dapat meningkatkan difusi obat menembus membran sel dan memberikan efek hidrasi kulit yaitu melunakkan lapisan keratin pada Stratum corneum [6].

Propilen glikol dipilih karena penggunaannya lebih aman, nyaman, tidak toksik dan hanya mengiritasi ringan jika dibandingkan dengan gliserin [7]. Diantara tiga konsentrasi propilen glikol yang digunakan yaitu $10 \%$, 20\%, dan $30 \%$ yang memberikan laju penetrasi yang paling baik terhadap ibuprofen sediaan gel adalah konsentrasi 30\% [8]. Selain itu terdapat penelitian lain yang menyebutkan bahwa konsentrasi propilen glikol sebesar 18,51\% sudah menunjukkan peningkat penetrasi ketoprofen sediaan transdermal patch [9].

\section{Bahan dan Metode Penelitian}

\subsection{Bahan}

Bahan yang digunakan dalam penelitian ini adalah ibuprofen (Merck), hidroksi propil metil selulosa (Merck), carbopol (Merck), etil selulosa (Merck), propilen glikol (Merck), polietilen glikol 400 (Merck), trinoalamin (Merck), kalium klorida (Merck), kalium fosfat dibasik (Merck), natrium fosfat dibasi (Merck), natrium klorida (Merck), asam klorida (Merck), etanol 96\% dan aquadest.

\subsection{Metode}

Sediaan patch dibuat dengan cara melarutkan $100 \mathrm{mg}$ ibuprofen menggunakan etanol $96 \%$ dan dituangkan kedalam campuran polimer yaitu HPMC, Carbopol, dan EC kemudian diaduk hingga larut. Larutan obat dan polimer yang sudah tercampur di tambahkan bahan tambahan lainnya yaitu propilen glikol, PEG-400, TEA diaduk hingga homogen. Setelah semua bahan sudah tercampur lalu dituangkan kedalam cetakan. Kemudian dikeringkan menggunakan oven pada suhu $50^{\circ} \mathrm{C}$ selama $20 \mathrm{jam}$. Rancangan formula patch dapat dilihat pada Tabel 1 .

\section{Hasil dan Pembahasan}

\subsection{Pengamatan organoleptik}

Hasil pengujian organoleptik patch dari ke-empat formula menunjukkan bahwa sediaan transdermal patch berbentuk lingkaran sesuai dengan cetakan yang digunakan dengan diameter permukaan sebesar 4,9 cm tidak menimbulkan bau, dan berwarna bening. Sediaan transdermal patch yang dihasilkan juga mempunyai kondisi permukaan yang kering dan tidak retak. Kondisi ini menunjukkan bahwa proses pengeringan pada suhu $50^{\circ} \mathrm{C}$ selama 20 jam merupakan kondisi yang optimum dalam segi pembuatan sediaan transdermal patch ibuprofen. Sediaan patch yang diperoleh dapat dilihat pada Gambar 1.

\subsection{Uji ketebalan}

Hasil uji ketebalan dalam satu patch menunjukkan bahwa rata-rata ketebalan formula 1 sebesar $0,142 \pm 0,008 \mathrm{~mm}$, formula 2 memiliki rata-rata ketebalan sebesar 0,154 $\pm 0,005$ $\mathrm{mm}$, formula 3 memiliki rata-rata ketebalan sebesar $0,17 \pm$ $0,01 \mathrm{~mm}$ dan formula 4 memiliki rata-rata ketebalan sebesar $0,184 \pm 0,005 \mathrm{~mm}$. Hasil pengujian tersebut menunjukkan bahwa bahan-bahan pada proses pembuatan patch telah tersebar secara merata pada sediaan patch dimana nilai ketebalan patch di berbagai titik memiliki perbedaan yang tidak `terlalu jauh. Hal ini dapat dilihat kecil nya nilai SD yang diperoleh dari masing-masing formula menunjukkan ketebalan antar permukaan dari masing-masing patch seragam. Hasil uji ketebalan sediaan patch dapat dilihat pada Tabel 2.

\subsection{Uji ketahanan lipat}

Uji ketahanan lipat dilakukan secara manual dengan cara melipat patch pada dua sisi berulang kali sampai rusak atau dilipat hingga 300 kali. Hasil dari uji ketahanan lipat dari keempat formula yaitu lebih dari 300 kali lipatan dan dapat dikatakan baik. Hal ini dikarenakan patch masih dalam keadaan baik, tidak rusak, tidak retak ketika dilakukan pengujian hingga nilai lebih dari 300 kali. Hasil uji ketahanan lipat dapat dilihat pada Tabel 3. 
Tabel 1

Rancangan formula patch ibuprofen

\begin{tabular}{ccccc}
\hline \multirow{2}{*}{ Bahan } & \multicolumn{4}{c}{ Formula (mg) } \\
\cline { 2 - 5 } & Formula 1 & Formula 2 & Formula 3 & Formula 4 \\
\hline Ibuprofen & 100 & 100 & 100 & 100 \\
\hline HPMC & 10 & 10 & 10 & 10 \\
\hline Carbopol & 10 & 10 & 150 & 10 \\
\hline Etil Selulosa & 150 & 150 & 200 & 250 \\
\hline Propilen Glikol & 0 & 65 & 65 & 65 \\
\hline PEG 400 & 65 & 15 & 15 & 15 \\
\hline TEA & 15 & 500 & 550 & 600 \\
\hline Jumlah & 350 & & &
\end{tabular}
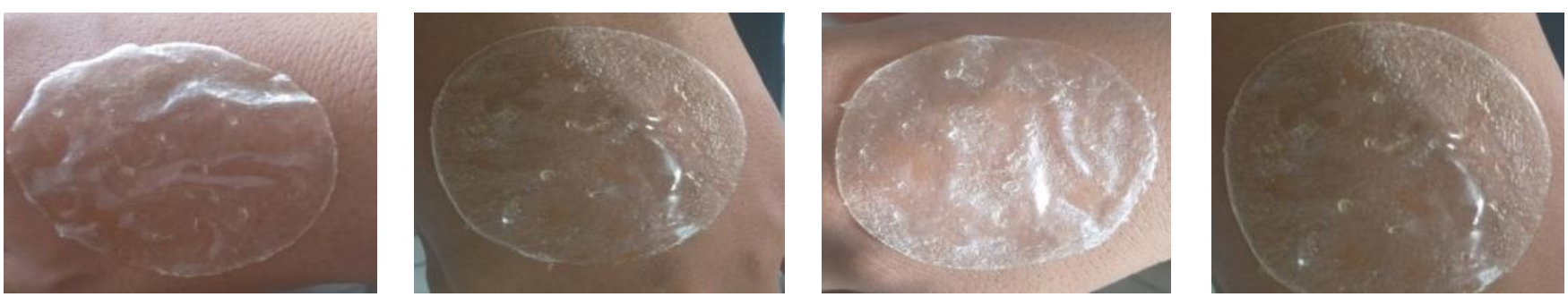

Gambar 1. Formula 1 (a); Formula 2 (b); Formula 3 (c); Formula 4 (d). Sediaan transdermal patch berwarna putih, kering dan tidak retak.

Tabel 2

Hasil uji ketebalan patch

\begin{tabular}{ccccc}
\hline \multirow{2}{*}{ Titik } & \multicolumn{4}{c}{ Ketebalan patch $(\mathbf{m m})$} \\
\cline { 2 - 5 } & Formula 1 & Formula 2 & Formula 3 & Formula 4 \\
\hline $\mathbf{1}$ & 0,15 & 0,16 & 0,18 & 0,19 \\
$\mathbf{2}$ & 0,15 & 0,16 & 0,18 & 0,19 \\
$\mathbf{3}$ & 0,13 & 0,15 & 0,17 & 0,18 \\
$\mathbf{5}$ & 0,14 & 0,15 & 0,16 & 0,18 \\
\hline Rata-rata \pm SD & 0,14 & 0,15 & 0,16 & 0,18 \\
\hline
\end{tabular}

\section{$3.4 \mathrm{Uji} \mathrm{pH}$}

Data hasil pengujian $\mathrm{pH}$ menunjukkan bahwa $\mathrm{pH}$ dari masing-masing formula memenuhi kriteria $\mathrm{pH}$ sediaan yang dapat di toleransi dan tidak mengiritasi kulit yaitu 4,5-6,5. Hasil uji pH untuk sediaan transdermal patch ibuprofen menunjukkan penurunan $\mathrm{pH}$ dari $\mathrm{F} 1>\mathrm{F} 2>\mathrm{F} 3>\mathrm{F} 4$, hal ini dikarenakan variasi konsentrasi propilen glikol, diketahui propilen glikol mempunyai pH 5,6 [10]. Hasil uji pH dapat dilihat pada Tabel 4.

\subsection{Hasil uji penetrasi}

Pengujian penetrasi dilakukan dengan menggunakan alat sel difusi franz. Setelah dilakukan uji penetrasi selama 8 jam dapat terlihat bahwa kadar kumulatif ibuprofen semakin meningkat seiring dengan bertambahnya waktu penetrasi. Selain itu dari kurva penetrasi ke-empat formula sediaaan patch ibuprofen juga dapat dilihat bahwa sampai menit ke-480 masing-masing formula belum menunjukkan keadaan jenuh. Hasil pengujian penetrasi secara statistik menunjukkan bahwa formula optimum dari ke-empat formula tersebut yaitu formula 3, karena formula 1 ke formula 3, dan formula 2 ke formula 3 berbeda signifikan, sedangkan formula 4 ke formula 3 tidak berbeda signifikan. Artinya apabila formula yang optimum merupakan formula 3 dengan jumlah konsentrasi propilen glikol $200 \mathrm{mg}$ maka dengan penambahan konsentrasi $250 \mathrm{mg}$ atau formula 4 tidak memiliki banyak perbedaan dengan formula 3 . Hasil pengujian kadar kumulatif penetrasi ibuprofen dalam sediaan transdermal patch dapat dilihat pada tabel 5 dan profil penetrasi ibuprofen dapat dilihat pada Gambar 2. 


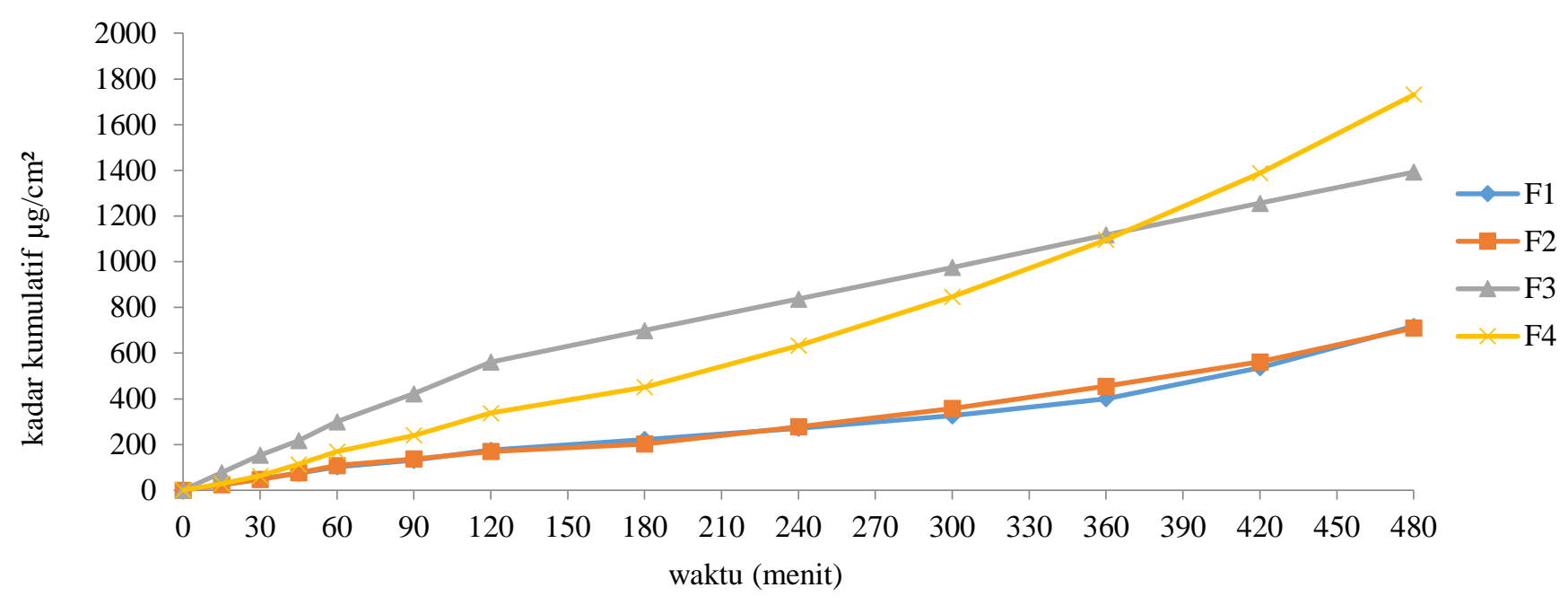

Gambar 2. Profil penetrasi patch ibuprofen dari ke-empat formula

Tabel 3

Hasil uji ketahanan lipat patch

\begin{tabular}{ccccc}
\hline \multirow{2}{*}{ Replikasi } & \multicolumn{4}{c}{ Ketahanan lipat patch } \\
\cline { 2 - 5 } & Formula 1 & Formula 2 & Formula 3 & Formula 4 \\
\hline $\mathbf{1}$ & $>300 \mathrm{kali}$ & $>300 \mathrm{kali}$ & $>300 \mathrm{kali}$ & $>300 \mathrm{kali}$ \\
$\mathbf{2}$ & $>300 \mathrm{kali}$ & $>300 \mathrm{kali}$ & $>300 \mathrm{kali}$ & $>300 \mathrm{kali}$ \\
$\mathbf{3}$ & $>300 \mathrm{kali}$ & $>300 \mathrm{kali}$ & $>300 \mathrm{kali}$ & $>300 \mathrm{kali}$ \\
\hline
\end{tabular}

Tabel 4

Hasil pengujian $\mathrm{pH}$ Patch

\begin{tabular}{ccccc}
\hline \multirow{2}{*}{ Replikasi } & \multicolumn{4}{c}{ pH permukaan } \\
\cline { 2 - 5 } & Formula 1 & Formula 2 & Formula 3 & Formula 4 \\
\hline $\mathbf{1}$ & 5,5 & 5,5 & 4,6 & 4,9 \\
$\mathbf{2}$ & 5,9 & 5,3 & 5,0 & 4,6 \\
$\mathbf{3}$ & 4,8 & 4,7 & 5,0 & 4,8 \\
\hline Rata-rata \pm SD & $5,4 \pm 0,556$ & $5,166 \pm 0,416$ & $4,866 \pm 0,230$ & $4,766 \pm 0,152$ \\
\hline
\end{tabular}

Tabel 5

Hasil pengujian penetrasi patch ibuprofen

\begin{tabular}{ccccc}
\hline Menit & Formula 1 & Formula 2 & Formula 3 & Formula 4 \\
\hline $\mathbf{0}$ & 0 & 0 & 0 & 0 \\
$\mathbf{1 5}$ & 24.10333 & 24.06933 & 76.997 & 28.84333 \\
$\mathbf{3 0}$ & 48.78233 & 47.57967 & 153.3307 & 62.67467 \\
$\mathbf{4 5}$ & 74.79667 & 76.05 & 217.49 & 113.538 \\
$\mathbf{6 0}$ & 102.0843 & 107.9033 & 300.089 & 168.7467 \\
$\mathbf{9 0}$ & 131.4957 & 137.0137 & 422.3703 & 240.0437 \\
$\mathbf{1 2 0}$ & 175.4143 & 169.6043 & 561.3543 & 337.5457 \\
$\mathbf{1 8 0}$ & 221.9897 & 202.471 & 699.682 & 451.4097 \\
$\mathbf{2 4 0}$ & 271.311 & 277.8303 & 837.3143 & 633.1917 \\
$\mathbf{3 0 0}$ & 325.8917 & 358.335 & 975.466 & 847.062 \\
$\mathbf{3 6 0}$ & 400.901 & 455.4753 & 1117.487 & 1096.191 \\
$\mathbf{4 2 0}$ & 536.464 & 562.211 & 1256.049 & 1388.051 \\
$\mathbf{4 8 0}$ & 717.0503 & 710.4167 & 1392.45 & 1732.081 \\
\hline
\end{tabular}




\section{Kesimpulan}

Karakteristik fisik organoleptis dari ke-empat formula diperoleh hasil yang sama yaitu tidak berbau, berwarna bening, kondisi permukaan kering dan tidak retak, dengan ketahanan lipat yang diperoleh yaitu $>300$ kali lipatan, hasil ketebalan yang diperoleh berkisar antara 0,142 - 0,184, dan pH sediaan transdermal patch ibuprofen berkisar antara 4,75,4 telah memenuhi persyaratan $\mathrm{pH}$ yang dapat ditoleransi yaitu 4,5-6,5.

Variasi konsentrasi propilen glikol $150 \mathrm{mg}, 200 \mathrm{mg}$, dan $250 \mathrm{mg}$ memberikan pengaruh terhadap laju penetrasi dari sediaan transdermal patch ibuprofen. Peningkatan konsentrasi propilen glikol menyebabkan meningkatnya jumlah obat yang berpenetrasi ke dalam kulit. Hal ini ditunjukkan dengan hasil penetrasi dimana laju penetrasi formula $4>$ formula $3>$ formula $2>$ formula 1 .

\section{References}

[1] Katzung, B.G. 2003. Drugs Used in Disorders of Coagulation, in: Basic \& Clinical Pharmacology. Mcgraw-Hill. 9th Ed.P.775-776.

[2] BNF. 2009. Bnf Children: The Essential Resource For Clinical Use Of Medicines In Children, Bmj Group, Germany.

[3] Waranugraha, Y., Putra, B.P. dan Suryana, B.P. Hubungan Pola Penggunaan OAINS dengan Gejala Klinis Gastropati pada Pasien Reumatik Relationship of NSAID Utilization Pattern
With Gastropathy Symptoms in Rheumatic Patient. Jurnal Kedokteran Brawijaya, 2010; 26 (2).

[4] Madhulatha, A. dan Naga, T.R. Formulation And Evaluation of Ibuprofen Transdermal Patches. International Journal Of Research In Pharmaceutical And Biomedical Sciences, 2013; 4 (1).

[5] Gungor, S., Erdal, M. E. dan Ozsoy, Y. 2012. Plasticizer in Transdermal Drug Delivery System. Recent Advances in Plasticizer. Beyazit-Istanbul: Turki

[6] Williams, A.C. dan Barry, B.W. 2004. Penetration Enhancers. Advanced Drug Delivery Reviews. 5 (6): 603-618.

[7] Rowe, R. C., Sheskey, P,.J. dan Quinn, M,E. 2009. Handbook of Pharmaceutical Excipients Sixth Edition. Pharmaceutical Press: London.

[8] Mehsen, M.B. Effect Of Propylene Glycol, Poly Ethylene Glycol 400 And $\mathrm{Ph}$ On The Release And Diffusion Of Ibuprofen From Different Topical Bases. AJPS, 2011; 9 No.1.

[9] Zakinah, H.R. 2016. Pengaruh Propilen Glikol dalam Patch Dispersi Padat Ketoprofen Terhadap Karakteristik Fisika Kimia da Laju Penetrasinya. [Skripsi]. Jember. Fakultas Farmasi Universitas Jember.

[10] Gaikwad, A.K. Transdermal Drug Delivery System: Formulation Aspect and Evaluation. Comprehensive Journal of Pharmaceutical Science, 2013; 1 (1).

[11] Wulandari, S.A.R. 2017. Formulasi dan Uji Aktivitas Antibakteri Stapylococcus Epidemidis Sediaan Mikroemulsi Ekstrak Daun Kersen (Muntingia Calabura Linn.) dengan Fase Minyak Isopropil Mirystate [Skripsi]. Malang: Fakultas Kedokteran Dan Ilmu Kesehatan Universitas UIN Malang. 